\title{
Predicting invasion patterns in coastal ecosystems: relationship between vector strength and vector tempo
}

\author{
Deniz Haydar*, Wim J. Wolff \\ Department of Marine Benthic Ecology and Evolution, Centre for Ecological and Evolutionary Studies, \\ University of Groningen, PO Box 11103, 9700 CC Groningen, The Netherlands
}

ABSTRACT: Oyster transports are among the leading anthropogenic vectors of coastwise introduction of nonindigenous species. Using the oyster industry of the Netherlands as a model system, we investigated the relationship between vector strength (number of invasions) and vector tempo (magnitude and frequency of transport) in analyzing and predicting invasion patterns. We reviewed literature on oyster-associated species introductions, analyzed the scale of commercial oyster imports, and collected and identified epiflora from Pacific oyster shells. A total of 35 protist, algal, and invertebrate species have been introduced to the Netherlands with oysters, and we found 41 species of macroalgae on transported oysters. However, the number of introductions and quantity of oysters imported are not necessarily positively correlated, particularly in the past $20 \mathrm{yr}$, when oyster imports decreased but the rate of introductions increased. The discrepancy between vector tempo and strength can be explained by unreported imports and vector characteristics: a single oyster may harbor a large number of species which are introduced with their substrate, thus facilitating establishment. Further, the recently developed extensive Pacific oyster reefs in Dutch waters provide a suitable substrate, enabling establishment even after low propagule pressure introduction events. Assumptions that are made about crucial parameters need to be reconsidered: reported propagule pressure is not the same as actual propagule pressure; per-episode diversity of potential inoculants is not at a fixed level without episodic unpredictable spikes, and the recipient environment is not static. With increasing interest in predicting invasion patterns, caution must be taken in assuming that reduced propagule pressure will lead to reduced invasions.

KEY WORDS: Vector strength - Vector tempo · Epibiota · Oyster translocations · Propagule pressure $\cdot$ Crassostrea gigas

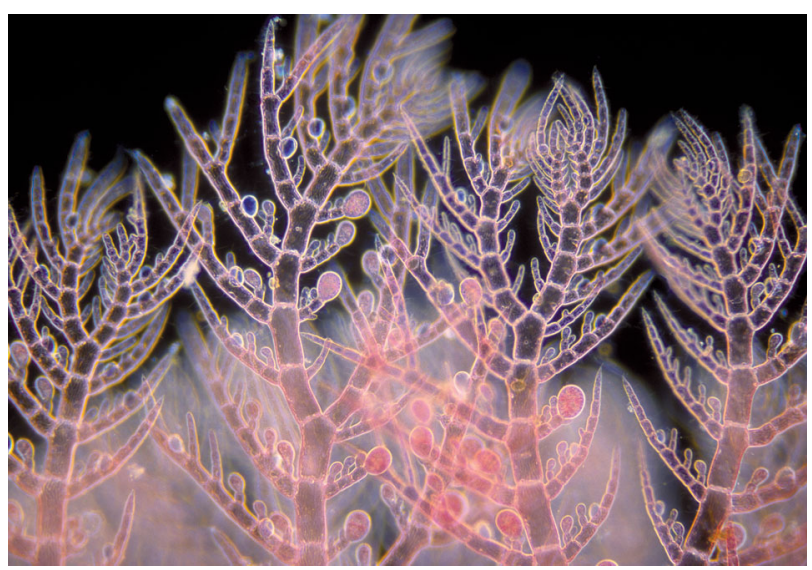

The cryptogenic red seaweed Pterothamnion plumula may be introduced as a hitchhiker on oyster shells.

Photo: Wim van Egmond

\section{INTRODUCTION}

Marine bioinvasions are increasing worldwide and continue to have great impact on receiving communities. In order to manage and prevent the further increase in numbers of introduced species, and thus the increased potential for negative effects, a better understanding of the process of biological invasions is necessary. The success of an introduction event depends on many variables, including the species involved, environmental characters of donor and recipient regions, and the anthropogenic vector (transport mechanism) that carries non-indigenous species to a region outside their native range. Characteristics of a vector, such as numbers of individuals released and 
number of introduction events (propagule pressure), the type of community transported and the route along which the vector travels, are further determinants of the potential success of introductions.

While the most effective way to prevent introductions is by intercepting or disrupting a vector, understanding the details of the pattern and process of a given vector is a prerequisite for undertaking management measures. Carlton \& Ruiz (2005) proposed a framework for vector science, in which they characterize 3 aspects of a vector: vector tempo (how a vector operates through time), vector biota (the organisms that are transported) and vector strength (the number of successful introductions by this vector). In this study, we analyzed these aspects using as a model system the transport of live oysters and their associated species.

Exploitation of oysters as a food source goes back to ancient times. As a result of centuries of overexploitation of wild stocks, oyster culture has been established worldwide, and in order to maintain oyster availability and high productivity, intra- and intercontinental movements of oysters commenced on a large scale in the 1700 s and 1800 s, respectively (Wolff 2005a). Nonindigenous oysters have been introduced and established permanently in at least 24 countries on all continents (except Antarctica) outside their native ranges (Ruesink et al. 2005). These oyster translocations are one of the major vectors for the introduction of associated species (Elton 1958).

The wild stocks of the native oyster Ostrea edulis have been extensively fished in the Netherlands since at least the 1600s (Smallegange 1696, Dijt 1961, Dijkema 1997). Overexploitation, introduced parasites, severe winters and changing hydrographic conditions resulted in the near extirpation of $O$. edulis from the Wadden Sea and the estuaries in the southwest Netherlands (Drinkwaard 1999, Wolff \& Reise 2002) (Fig. 1). To compensate for depleted O. edulis stocks, oysters of various species were imported from other regions into the Netherlands as early as the 1700s (Wolff \& Reise 2002). O. edulis and the Portuguese oyster Crassostrea angulata were imported from other European countries, and by the 1880s, the American oyster $C$. virginica was imported from the USA. However, neither $C$. angulata (now recognized as native to the Western Pacific) nor C. virginica established selfsustaining populations in the Netherlands (Wolff \& Reise 2002, Wolff 2005b).

The Pacific oyster Crassostrea gigas was imported as spat or seed (newly settled oysters) into the Oosterschelde from British Columbia, Canada, and Japan, starting in 1964 (Shatkin et al. 1997, Drinkwaard 1999), and adult Pacific oysters were imported in 1971 (Wolff \& Reise 2002). The Pacific oyster is now the most

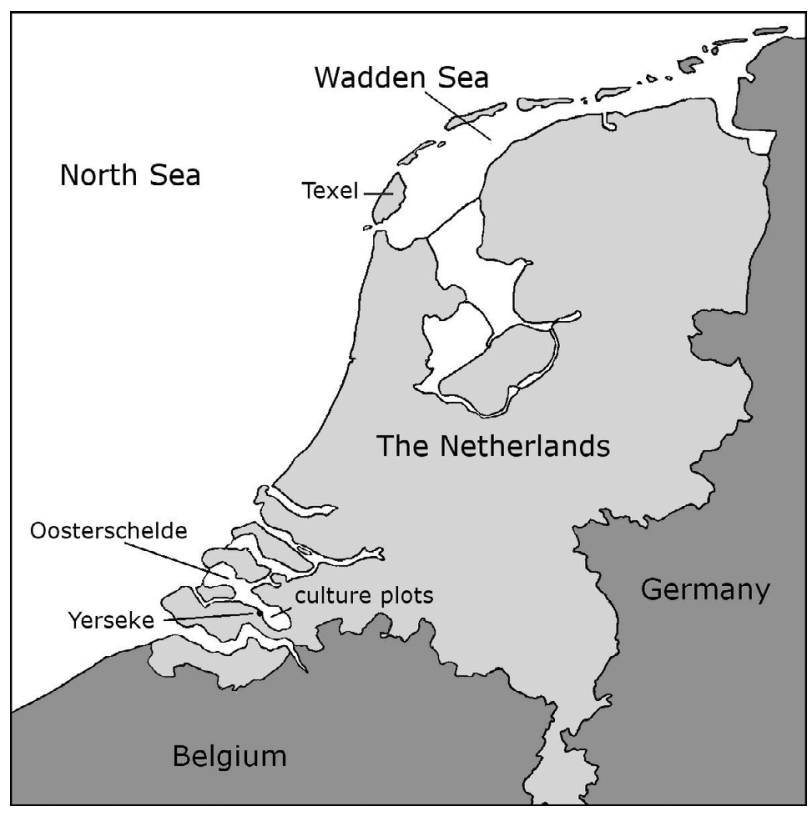

Fig. 1. The Oosterschelde Estuary in the southwest Netherlands is the center of the Dutch oyster culture. The Pacific oyster has colonized the estuaries in the southwest, as well as the Wadden Sea in the north

important cultured oyster in the Netherlands, and, in contrast to earlier importations, C. gigas became established in the wild, and maintains reproducing populations in the Oosterschelde, the center of oyster culture, after strong spatfalls in 1976 and 1982. C. gigas has also spread to the Wadden Sea, possibly as the result of a deliberate introduction to the island of Texel (Tydeman 2008), from where it spread eastward (Fig. 1). The Pacific oyster was also deliberately introduced to the island of Sylt in the German Wadden Sea, from where it spread north and south, and since 2004, the entire Wadden Sea has been colonized (Reise et al. 2005). The Pacific oyster now forms extensive and dense intertidal and subtidal beds and reefs in Dutch coastal waters (Dankers et al. 2006, Smaal et al. 2009, Troost 2010).

Although only the Pacific oyster became established in Dutch coastal waters, imports of this and other oyster species into Europe have resulted in the introduction of a number of associated species, such as the slipper limpet Crepidula fornicata, introduced with American oysters (Blanchard 1997), and the brown seaweed Sargassum muticum, imported with Pacific oysters (Critchley et al. 1990). Ongoing commercial movements of oysters within European waters are believed to have resulted in rapid secondary spread of introduced species (Grizel \& Héral 1991). Evaluation of possible vectors for all non-indigenous marine and estuarine species in the Netherlands showed that oys- 
ter imports are one of the strongest single vectors for introduction (Wolff 2005b). Many first records of introduced species are from the Oosterschelde, near areas of extensive oyster culture (Maggs \& Stegenga 1999, Wolff 2005b). Possible explanations for the high proportion of oyster-associated introductions (and consequently the low proportion of shipping-associated introductions) are the underestimation of the number of non-indigenous species that were historically introduced as fouling organisms on the hull of ships and the fact that the Netherlands export ballast water rather than receiving large quantities from other regions (AquaSense 1998). More significantly, the frequency and scale of oyster translocations and the characteristics of this vector - the rugged and complex shells of oysters offer ample opportunities for epiflora and epifauna to settle and survive transport to other regionsmay also explain the relatively high number of oysterassociated introductions.

This high number of introductions by oyster transports as a vector in the Netherlands is in contrast with several studies from other regions, which suggest that shipping-associated vectors, either hull fouling or ballast water, are the strongest anthropogenic vectors of introduction (Ruiz et al. 2000, Hewitt et al. 2004, Gollasch 2006). In the present study, we investigate the relationship of vector strength to vector tempo in invasion ecology, to explain the relatively high number of species introduced by this vector into Dutch coastal waters.

\section{MATERIALS AND METHODS}

Vector strength: oyster-associated introductions. Based on literature, an overview was created of marine flora and fauna hypothesized or known to have been introduced to Dutch coastal waters with oyster imports. We included species that were directly imported from other biogeographic regions into the Netherlands with oysters, as well as those that were first introduced elsewhere in the Northern European Seas and the South European Atlantic Shelf ecoregions (Spalding et al. 2007) with oysters and may have spread to the Netherlands by natural dispersal or with anthropogenic vectors. We assume that the probability of recording an invasion has not changed over time. We included the first record and probable vector of the species of concern both in Europe and in the Netherlands, as well as their global distribution and native range.

Vector tempo: oyster imports into the Netherlands. Quantitative data on oysters imported commercially from 1960 to 2008 were obtained from Statistics Netherlands (CBS). Import data have been categorized differently over the years. From 1960 to 1974 imported oysters were characterized as either 'seed oysters' or 'other oysters'; after 1974 a distinction was made between 'live Ostrea spp. oysters $<40 \mathrm{~g}$ ' and 'other oysters'. In both periods, the 'other oysters' category included all oyster species that were imported alive, fresh, cooled, frozen, dried, salted, or pickled, and thus included oysters intended for direct consumption as well as oysters that were relaid in recipient waters for storage and/or growth. Live adult oysters that are imported for direct consumption are often kept on culture plots or in tanks on the shore with running seawater before sale, and introduction of non-indigenous species may thus still take place, even though the oysters concerned are not intended for restocking.

The amounts of oysters imported are given as the quantity of each category of imported oysters per year. For the analysis of origins of annual oyster imports, we pooled all data, not making a distinction between the 'seed oysters', 'live Ostrea spp. <40 g', and 'other oysters', since the data did not always permit making this distinction.

Vector biota: diversity of oyster epiflora. Pacific oysters Crassostrea gigas were dredged from subtidal culture plots on the eastern end of the Oosterschelde estuary, just off the coast of Yerseke (Fig. 1), by a commercial oyster grower. Oysters are moved at least twice a year between culture plots by the growers for optimum growth and shell form. A total of 9 samples of oysters, composed of 30 oysters each, were collected in May 2003, September to December 2003, February to March 2004 and June 2004 from varying culture plots. After dredging, the oysters were handled as if they were to be transported to other regions, either for direct sale, or for (temporary) relaying in other estuaries. This meant that the oysters were superficially cleaned by hand by the oyster grower. Next, they were transported to the laboratory in a cooler and kept in a mesh bag at $11^{\circ} \mathrm{C}$ for $3 \mathrm{~d}$ in order to mimic transport conditions as they are encountered when oysters are moved between culture sites or seafood markets in different parts of Europe.

After this, macroepiflora were collected from 30 individual oysters per sample under a stereo-microscope, fixed in $4 \%$ formalin, and mounted for permanent preservation on microscopic slides in a syrup medium (Stevenson 1984). Some algae were stained as reference material using Fast Green FCF. Slides were examined microscopically (magnification 100 to $200 \times$ ) and species were identified with the help of a phycological expert. The epiflora of a total number of 270 oysters was analyzed. Data were grouped for all oysters, resulting in the percentage of the total number of oysters carrying individual species of macroalgae, and the seasonal occurrence of the most common species on oyster shells. 
Small species of macroalgae were only recorded if they were found growing as epiphytes on the collected macroalgae. Quantifying the number of individuals encountered per species was impossible because of the small size of specimens and the presence of many fragments of algae. Microalgae were not recorded. Epifauna was collected as well, but the data were not analyzed in detail because of major taxonomic uncertainties presented by the often small specimens.

In order to evaluate our sampling effort, we created a species accumulation curve for all 270 oysters analyzed. We assigned random numbers to individual oysters and plotted cumulative numbers of species by adding the new species found in consecutive randomly numbered oysters. The species accumulation curve was fitted and extrapolated to calculate expected species richness using the equation:

$$
\text { Cum }=\frac{a N}{(1+b N)}
$$

where Cum is the cumulative number of species, $N$ is the number of oysters and $a$ and $b$ are constants; $a / b$ is the maximum species richness (Bunge \& Fitzpatrick 1993). The equation was rewritten as:

$$
\frac{N}{\operatorname{Cum}}=\left(\frac{b}{a}\right) N+\left(\frac{1}{a}\right)
$$

and was fitted by linear regression with least squares to estimate $a$ and $b$.

To check whether any propagules or individuals on the shells would be too small and would be missed by only visually checking and collecting epiflora, an additional sample of about 30 oysters was taken in February 2005. The animals were removed from their shells, and the valves were kept in experimental tanks with constant artificial seawater (to ensure absence of exogenous propagules) at $12^{\circ} \mathrm{C}$ and $30 \mathrm{psu}$. We analyzed the total epiflora growing on the valves after 1 mo for presence of species that we had not recorded in our monthly samples of oysters that were analyzed $3 \mathrm{~d}$ after collection. As resting stages such as cysts are commonly formed in winter, and most algae bloom in summer when they would be large enough to observe without culturing, we only cultured algae on the shells of oysters collected during winter.

The distribution of each species was obtained from AlgaeBase (Guiry \& Guiry 2009). A status was assigned to each species: native, introduced, or cryptogenic. Cryptogenic species are those species that are neither demonstrably native nor introduced (Carlton 1996). The cryptogenic status was assigned based on association with oysters and a disjunct distribution pattern.

\section{RESULTS}

\section{Vector strength: oyster-associated introductions}

Table S1 in the Supplement at www.int-res.com/ articles/suppl/m431p001_supp.pdf presents an overview of the 35 established non-indigenous plant and animal species in the Netherlands that are associated with oyster translocations. The time elapsed between the first observation elsewhere in Europe and the first observation of the same species in the Netherlands ranges from $1 \mathrm{yr}$ (Coscinodiscus wailesii) to $128 \mathrm{yr}$ (Neosiphonia harveyi). The average time between the first introduction elsewhere in Europe and the first record of the same species in the Netherlands is $29 \mathrm{yr}_{\text {; }}$ $57 \%$ are recorded within 20 yr after their first European record. For 4 species, the first northwestern European detection occurred in the Netherlands (Smittoidea prolifica, Colaconema daviesii, Dasya baillouviana and Polysiphonia senticulosa).

Red algae (Rhodophyceae) represent the largest taxonomic group (39\%) introduced by this vector. Of all associated introductions, $45 \%$ originate from the Northwest Pacific; these are assumed to have been introduced with Pacific oyster imports, either directly from Japan or via British Columbia and/or France. The Northwest Atlantic is the origin of $20 \%$ of oysterassociated introductions; these are likely to have been introduced with shipments of the American oyster Crassostrea virginica.

The numbers of first observations of oyster-associated introductions that resulted in the establishment of nonnative populations (i.e. established introductions) from 1891 to 2009 is shown in Fig. 2. There is an increasing trend in the rate of introductions, with a peak of 9 spe-

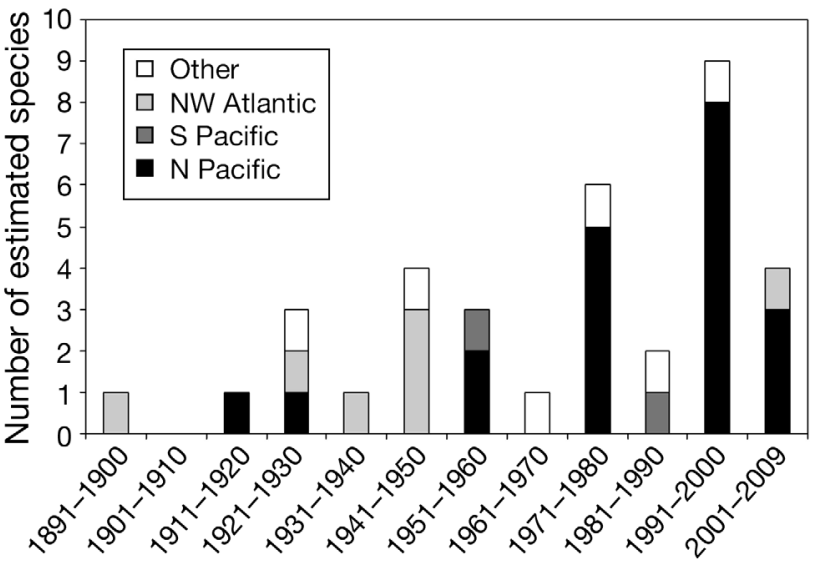

Fig. 2. Established oyster-associated introductions in the Netherlands per decade from 1891 to 2009. Dates of first observations of introduced species that are now established in Dutch coastal waters were used. Regions of origin for the established introductions are indicated, see legend 


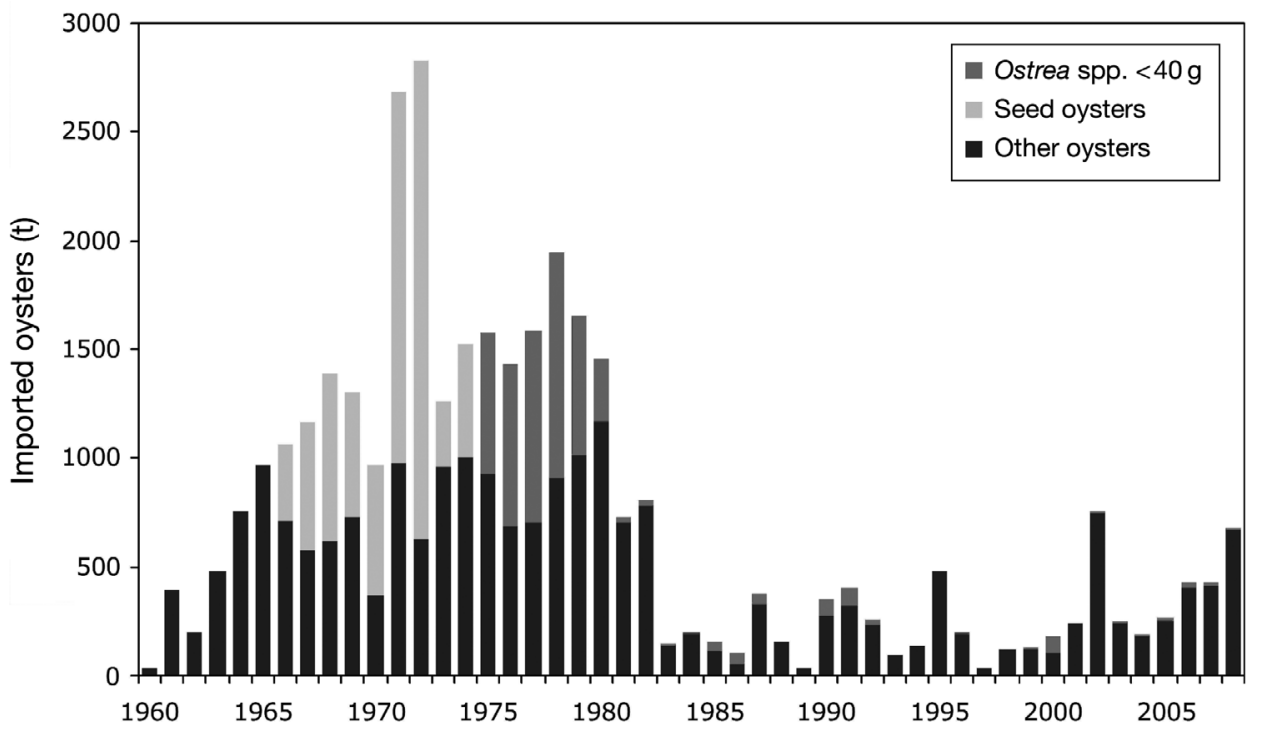

Fig. 3. Oyster imports into the Netherlands from 1960 to 2008. Data were obtained from Statistics Netherlands (CBS). Imports were split into 'other oysters' (live, fresh, dried, pickled, frozen, larger than $40 \mathrm{~g}$ ), 'seed oysters' and 'Ostrea spp. $<40 \mathrm{~g}$ '. The latter 2 categories are both intended for restocking culture plots, the 'other oysters' category includes oysters imported for direct sale and consumption, and oysters that are relaid in Dutch waters cies between 1991 and 2000. These all originate from the Northwest Pacific Ocean, and were presumably introduced with Crassostrea gigas.

\section{Vector tempo: oyster imports into the Netherlands}

The commercial oyster import data from 1960 to 2008 show that quantities of imported oysters differed greatly among years (Figs. 3 \& 4). The maximum was nearly 3000 t in 1971 and 1972, of which more than half was oyster seed. After 1982, imports of oysters into the Netherlands declined, to increase again after 2002.
Although the definition of import categories suggests that Crassostrea seed is included under 'other oysters', this is not certain, and it may have been reported as 'Ostrea spp. <40 g' as well. The 'other oysters' category includes larger live oysters of the various Ostrea and Crassostrea species. However, since these are pooled with oysters that are directly sold for consumption, it is not known what proportion of this category was relaid in Dutch waters (Fig. 3).

The origin of the imported oysters changed over time (Fig. 4). Until the 1970s, oysters were mainly imported from France and Portugal, which included imports of the non-indigenous Portuguese oyster Crassostrea

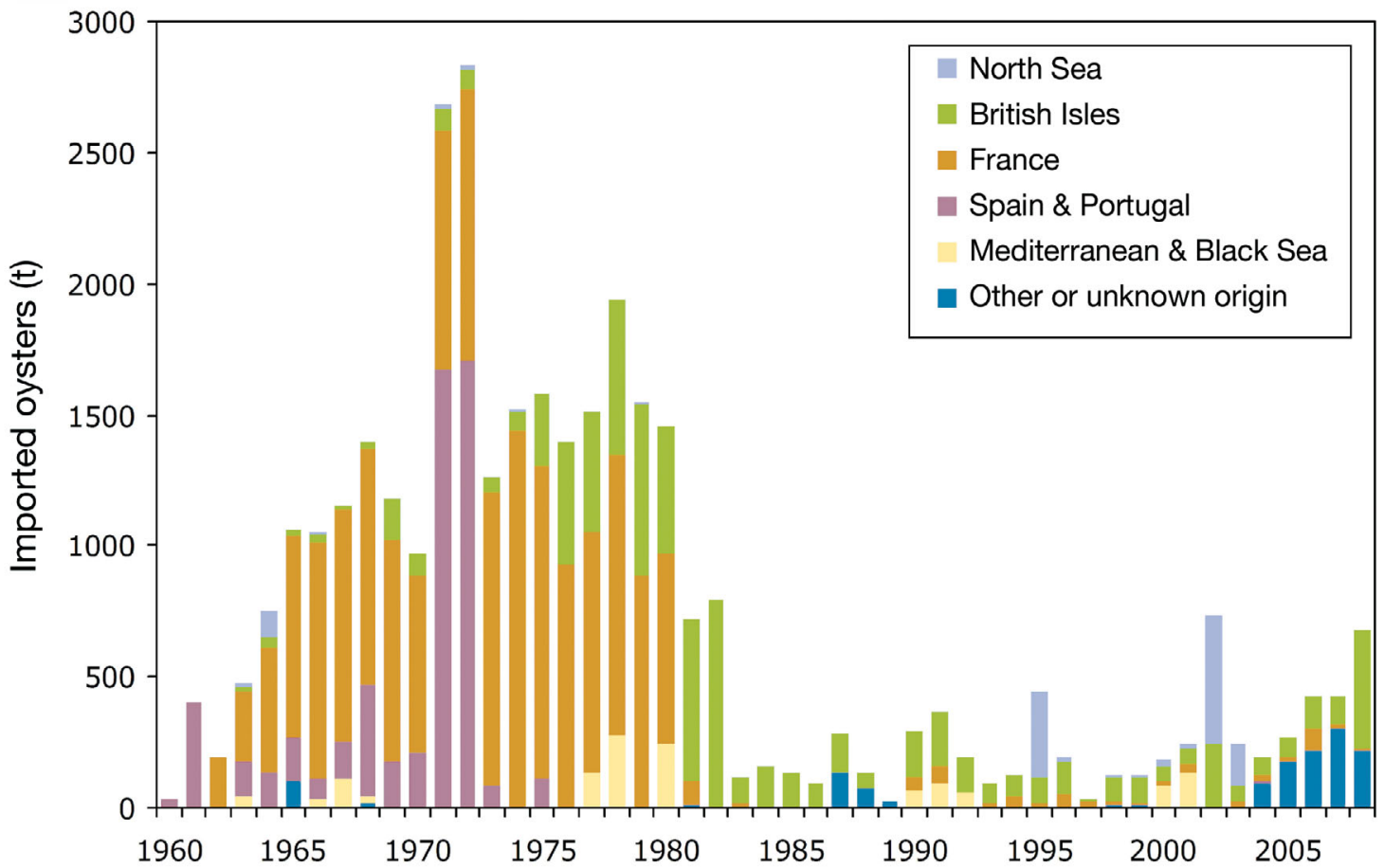

Fig. 4. Oyster imports into the Netherlands from 1960 to 2008. Data from Statistics Netherlands (CBS). North Sea does not include the east coast of the British Isles 
angulata. After 1980, the British Isles and other North Sea countries (Belgium, Germany, Denmark and Norway) became the predominant origin for imported oysters. Quantities of oysters directly imported from the Northwest Pacific (Japan, Korea) were very small, ranging from 227 to $3383 \mathrm{~kg}$, and the reported imports occurred infrequently $(1974,1989,1996,1997,1999$ to 2003), but became more frequent from 1996. Between 1960 and 2008, reported imports of oysters from Canada occurred in 1998 and 1999, and amounted to a total of $2678 \mathrm{~kg}$.

\section{Vector biota: diversity of oyster epiflora}

A total of 41 taxa of macroalgae (2 brown algae, 10 green algae and 29 red algae) was identified from the oyster shells; 37 of these were identified to species level (Table S2 in the Supplement at www.int-res.com/ articles/suppl/m431p001_supp.pdf). The number of macroalgal species found on a single oyster ranged from 0 to 14 , with an average of 4 species $( \pm 3$ SD) per oyster.

The species accumulation curve (Fig. 5) shows the observed cumulative number of macroalgal species up to 270 oysters sampled, and the expected cumulative number of species up to 500 samples. The expected cumulative number of species was computed using linear regression by fitting with least squares, resulting in $\frac{N}{\text { Cum }}=0.0226+0.5332\left(\mathrm{R}^{2}=0.9979\right)$. The estimates of the parameters $a$ and $b$ were obtained from this equa-

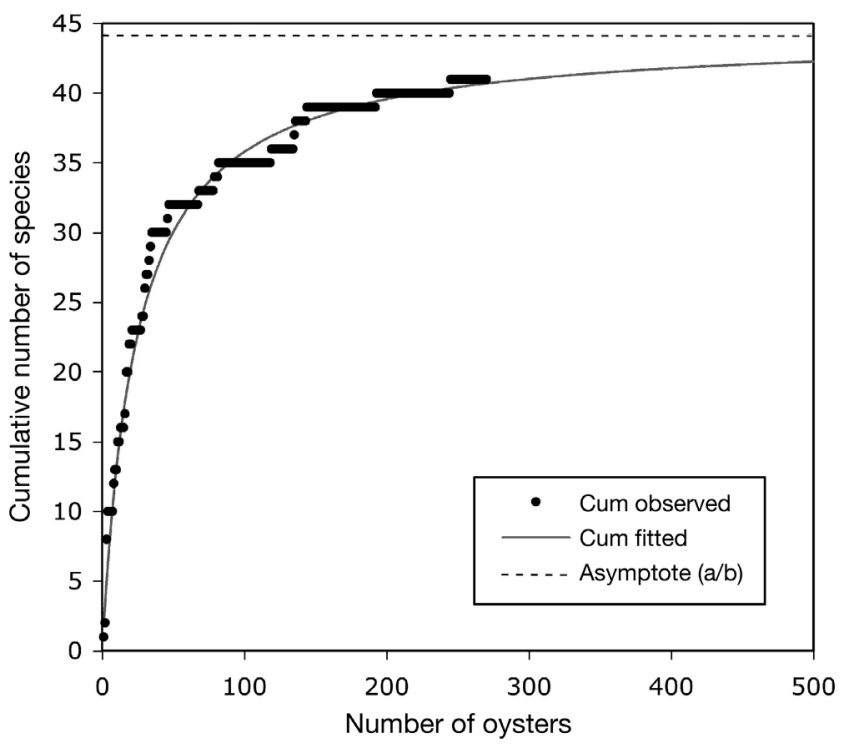

Fig. 5. Species accumulation curve for the macroalgal taxa encountered on oyster shells. The dots are the cumulative number of species on randomly numbered oyster shells, the solid line is the estimated cumulative number of species up to 500 individual oysters and the dashed line is the maximum expected number of taxa tion, and were used to compute the expected maximum number of species (the asymptote $\frac{a}{b}$ ) and the cumulative number of species up to 500 individual oysters $\left(\mathrm{Cum}=\frac{1.86 N}{1+0.042 N}\right)$. The cumulative number of species observed on 270 oysters was 41; the expected maximum species richness was 44. Analyzing 230 additional oysters (i.e. up to 500 oysters) would have resulted in the discovery of 1 additional species, and thus the species diversity of macroalgae was well captured in our sample size.

All identified species had previously been reported from Dutch coastal waters. The majority of the identified macroalgae are considered native; 9 species are introduced. In Table S2 in the supplement, we included distribution records of all species, and based on these records and the association with oysters and other anthropogenic vectors, we assigned a cryptogenic status to 23 species. Of the 10 species that occur on more than $15 \%$ of all oysters, 5 are introduced (Heterosiphonia japonica, Polysiphonia senticulosa, Dasya baillouviana, Antithamnionella spirographidis, Agardhiella subulata). H. japonica was by far the most common species: it occurred on $54 \%$ of all examined oysters.

Samples were taken year-round and were grouped into spring \& summer and fall \& winter. Seawater temperatures are higher in spring and summer, and most species of algae in the Oosterschelde are more abundant during those months. Transferring oysters during this period would be expected to result in a higher probability of introducing associated species. The seasonality of 10 algal species that occurred on more than $15 \%$ of all oysters is presented in Fig. 6. The majority of species are more common in spring \& summer. Three taxa show a higher occurrence in the colder months: foliose Ulva sp., Antithamnionella spirographidis, and Polysiphonia senticulosa. However, seasonal differences were small. The most common species, Heterosiphonia japonica, is very abundant year round.

Culturing of the algae in seawater tanks for $1 \mathrm{mo}$ resulted in high growth of opportunistic species, particularly tubulose (enteromorphoid) Ulva spp. However, it did not yield any species that had not already been encountered on the 270 oysters analyzed.

\section{DISCUSSION}

Vector strength (the number of successful introductions resulting from a particular vector) is often assumed to be correlated with vector tempo (the quantity of a given vector, e.g. tonnes of oysters or $\mathrm{m}^{3}$ of ballast water, released over a given time period). However, in the system studied here, with the exception of the 1970 s, there is no correlation between vector tempo and vector strength in the same period. 


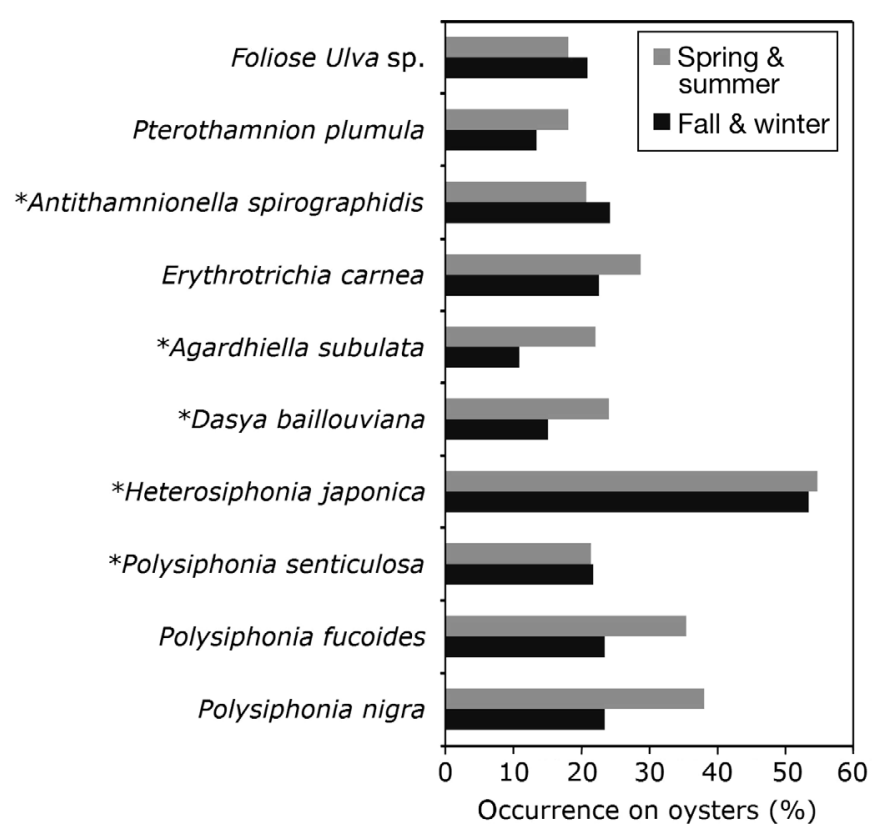

Fig. 6. Seasonality of the most abundant identified macroalgae from oyster shells (occurring on $>15 \%$ of all oysters examined). The frequency of occurrence of a species is indicated as a percentage of oysters on which this species was present. Fall \& winter includes samples taken in October, November, December and February $(\mathrm{n}=120)$; spring \& summer includes March, April, May, June and September ( $\mathrm{n}=150$ ).

${ }^{*}$ Introduced species

The number of oyster-associated introductions has increased since the 1970s, even though oyster imports drastically decreased from 1981 onwards (Fig. 3). We consider 3 possible reasons for this: (1) an increase in available habitat for oyster-associated species, despite the lower apparent vector strength, (2) an underestimate of the vector itself, and (3) the characteristics of the vector.

\section{Available habitat}

Successful establishment of species depends upon a very large number of variables, but available habitat is often a striking parameter. The rapidly growing Pacific oyster reefs in the Netherlands form an essentially new habitat for associated species, and are likely to facilitate the establishment of associated non-indigenous species. In the Oosterschelde, habitat modifications may have further facilitated colonization: the estuary now has higher temperatures and a changed hydrography due to the construction of a storm-surge barrier (Nienhuis \& Smaal 1994), changes that promote establishment and spreading of non-indigenous species in other disturbed systems (Occhipinti Ambrogi \& Savini 2003).

\section{Unreported imports}

Commercial oyster imports may, of course, be underreported. We did not find records of imports of Pacific oysters in the 1960s from British Columbia and Japan, although we know that they did take place and resulted in the establishment of the Pacific oyster in Dutch coastal waters (Shatkin et al. 1997, Drinkwaard 1999, Wolff \& Reise 2002). Imports of oyster seed for restocking culture areas have nearly ceased since 1980 (Fig. 3) due to the fact that the Pacific oyster has established self-sustaining populations in Dutch waters. Imports of 'other oysters' are ongoing and also include live oysters that may be kept in (or close to) the Oosterschelde. These translocations of oysters within Europe are also suspected of not always being reported to authorities (Verlaque 2001), but secondary spread of associated non-indigenous species provides evidence of ongoing transports. A clear example is the red alga Lomentaria hakodatensis, first observed in the Thau Lagoon in the Mediterranean in 1979, after which it was found in Brittany in 1984, and from where it 'jumped' to the Oosterschelde in 2004 (Verlaque 2001, Stegenga 2004). It has not been reported from areas in between these important oyster culture sites, and unreported oyster translocations are the only possible explanation for this secondary spread.

\section{Vector characteristics}

Finally, the topographically complex nature of oyster shells can permit a large number of species to exist on a single shell-essentially meaning that a small number of oysters could be involved in the translocation of a large number of species, even if such episodes are rare events. European trade regulations stimulate shellfish movements within Europe, and other shellfish are imported to the Oosterschelde as well. The mussel Mytilus edulis is imported from other European countries as seed for restocking Dutch cultures, and despite a risk analysis (Wijsman \& De Mesel 2009), at least 2 non-indigenous species, the Atlantic oyster drill Urosalpinx cinerea (pre-identified in the analysis report as a high-risk species) and the Manila clam Ruditapes philippinarum, have recently been introduced via mussel imports from the United Kingdom and Ireland (Faasse \& Ligthart 2008, 2009).

\section{Oyster-associated introductions}

The overview of 35 species presented here is the most up-to-date list of invertebrates and algae associated with imports of oysters (Table S1 in the Supplement). 
Detailed knowledge of the impact of these introduced species on the receiving ecosystem is lacking, but some of them negatively affect shellfisheries, as they overgrow oysters (e.g. Heterosiphonia japonica, A. Cornelisse pers. comm.), hamper growth (Polydora hoplura) (Korringa 1951, Royer et al. 2006) or cause mortality (Bonamia ostreae in Ostrea edulis) (Culloty et al. 1999). Crassostrea gigas imports are responsible for the largest number of introductions, mostly from the Northwest Pacific Ocean. Most secondary introductions are probably the result of ongoing oyster movements within Europe. Movements of oysters within Europe not only accelerate secondary spread of nonnative species, but may also result in (further) regional mixing of native and cryptogenic populations.

\section{Oyster epiflora}

The epiflora on oysters from the Oosterschelde was present throughout the year, and occurrence of species did not differ between spring \& summer and fall \& winter (Fig. 6). Some of the algae with the highest occurrence on oyster shells (Agardhiella subulata, Dasya baillouviana, Heterosiphonia japonica and Polysiphonia senticulosa) are also the dominant macroalgal species on other substrates in parts of the Oosterschelde, at the expense of native species (Stegenga et al. 2007). However, the seasonality of these species described by Stegenga et al. (2007) is not reflected in our results, possibly because we did not record size or biomass of algae. Occurrence of specimens large enough to identify to species level, of nearly all species throughout the year, demonstrates successful operation of this vector in all seasons. Small numbers of oysters from any given location at any time of the year translocated elsewhere may carry a substantial number of associated flora, including non-native species.

Other authors have also studied the occurrence of algae and invertebrates on oyster shells. Korringa (1951) made an inventory of the epifauna of Ostrea edulis from the Oosterschelde. He listed 134 animal species from shells that were not cleaned, which may explain the high number of taxa found. Schodduyn (1931) studied epiflora as well as epifauna of $O$. edulis transferred from the British Isles to northern France. He found 52 species of invertebrates and 14 species of macroalgae, of which 9 were red algae.

More recently, Mineur et al. (2007) investigated the epiflora on cleaned valves of Pacific oysters from the Thau Lagoon on the Mediterranean coast of France. The number of macroalgal species recorded from our oysters (37 identified species, see Table S2 in the supplement) is lower than the number of species found on Thau lagoon oysters (46 species). This can be ex- plained by the fact that the Thau Lagoon is richer in macroalgal species (Stegenga et al. 1997, Verlaque 2001), and harbors an exceptionally high number of introduced macroalgae, particularly from the Northwest Pacific Ocean (Verlaque 2001). This said, the epifloral communities are similar relative to taxonomic groups and species composition: on the Thau Lagoon oysters the Rhodophyceae were also the dominant group and 17 species recorded on oysters from the Oosterschelde were also found on Thau Lagoon oysters (Mineur et al. 2007).

\section{Cryptogenic species}

Based on disjunct or cosmopolitan distribution patterns, and the association with oysters, we assigned a cryptogenic species status to 23 of the 36 algae we identified to species level (Table S2 in the supplement). Historical oyster translocations go back to at least the 18th century, when Ostrea edulis was exchanged between European countries (Wolff \& Reise 2002), and possibly even the 16th century, when the Portuguese oyster Crassostrea angulata was introduced to Europe from Asia (Carlton 1999, Wolff 2005b). Historical introductions with these early oyster relayings may have resulted in cosmopolitan or disjunct distributions of species we now call native, and numbers of oyster-associated introductions will be underestimates.

\section{Vector tempo and vector strength}

There appears to be some association between vector tempo and vector strength. In 1971 to 1972 large quantities of oysters and in particular oyster seed, mostly from France and Portugal, were imported to the Netherlands (Fig. 3), and there is a peak in the number of associated introductions in the decade of 1970 to 1979 (Fig. 2). However, the 1970s are the only period that demonstrates this expected positive association between vector tempo and vector strength.

The assumptions made about the parameters that influence invasion success can explain the absence of a clear association between vector tempo and strength. Reported propagule pressure is not necessarily the same as actual propagule pressure; oyster imports may be underreported or not reported at all. The perepisode diversity of potential inoculants is not generally at a fixed level, but may show episodic - albeit unpredictable-spikes, such as might occur when oysters with unusually high epibiotic diversity are transported. Lastly, the recipient environment does not remain static, and changes in e.g. available habitat 
may facilitate successful establishment of non-indigenous species. These insights translate to other vectors as well. For ballast water management, for example, the high amount of unreported ballast water combined with that falsely declared as treated/exchanged, the potential for even one ship to carry a very large number of species (McCarthy \& Crowder 2000) and fundamental changes in environmental factors in the target region (such as warming waters) could all lead to vastly over-simplified models of invasion management. With increasing interest in the prediction of invasion patterns and the prevention of invasions, caution must be taken in assuming that reduced propagule pressure will lead to reduced rates of invasion.

Acknowledgements. We are grateful to A. Cornelisse for providing oyster samples, L. Venekamp for helping collect epiflora from oyster shells and the culturing experiments, H. Stegenga for help in identifying macroalgal samples, K. Troost for establishing contact with A. Cornelisse and transporting oyster samples, J. Carlton and H. J. Hoving for comments on earlier versions of this manuscript, and L. Dam for help with the species accumulation curve. This research was supported by the Dutch National Science Foundation; Earth and Life Science (NWO-ALW) project 885.10.312.

\section{LITERATURE CITED}

AquaSense (1998) Ballast water. Overview of available data and estimation of possible risks. Rep. No. 98 to Netherlands Ministry of Transport, Public Works and Water Management, North Sea Directorate, Amsterdam

Blanchard M (1997) Spread of the slipper limpet Crepidula fornicata (L. 1758) in Europe. Current state and consequences. Sci Mar 61(Suppl. 2):109-118

Bunge J, Fitzpatrick M (1993) Estimating the number of species: a review. J Am Stat Assoc 88:364-373

Carlton JT (1979) History, biogeography, and ecology of the introduced marine and estuarine invertebrates of the Pacific coast of North America. PhD thesis University of California, Davis

Carlton JT (1996) Biological invasions and cryptogenic species. Ecology 77:1653-1655

Carlton JT (1999) Molluscan invasions in marine and estuarine communities. Malacologia 41:439-454

Carlton JT, Ruiz GM (2005) Vector science and integrated vector management in bioinvasion ecology: conceptual frameworks. In: Mooney HA, Mack RN, McNeely JA, Neville LE, Schei PJ, Waage JK (eds) Invasive alien species-a new synthesis. Island Press, Washington, p 36-58

Critchley AT, Dijkema R (1984) On the presence of the introduced brown alga Sargassum muticum, attached to commercially imported Ostrea edulis in the S.W. Netherlands. Bot Mar 27:211-216

Critchley AT, Farnham WF, Yoshida T, Norton TA (1990) A bibliography of the invasive alga Sargassum muticum (Yendo) Fensholt (Fucales; Sargassaceae). Bot Mar 33:551-562

Culloty SC, Novoa B, Pernas M, Longshaw M, Mulcahy MF, Feist SW, Figueras A (1999) Susceptibility of a number of bivalve species to the protozoan parasite Bonamia ostreae and their ability to act as vectors for this parasite. Dis Aquat Org 37:73-80
Dankers NMJA, Meijboom A, de Jong ML, Dijkman EM and others (2006) De ontwikkeling van de Japanse oester in Nederland (Waddenzee en Oosterschelde). Rep C040/06, Wageningen IMARES, Yerseke

de Blauwe H, Faasse M (2004) Smittoidea prolifica Osburn, 1952 (Bryozoa, Cheilostomatida), a Pacific bryozoan introduced to the Netherlands (Northeast Atlantic). Bull Kon Belg Inst Natuurwet Biologie 74:33-39

Dijkema R (1997) Molluscan fisheries and culture in the Netherlands. NOAA Tech Rep NMFS 129:115-135

Dijt MD (1961) Texelse oesters, aantekeningen over opkomst en verval. Visserijnieuws 13:99-102

Drinkwaard AC (1999) History of cupped oyster in European coastal waters. Aquac Eur 24:7-11, 41

Elton CE (1958) The ecology of invasions by animals and plants. Methuen, London

Eno NC, Clark RA, Sanderson WG (1997) Non-native marine species in British waters: a review and directory. Joint Nature Conservation Committee, Peterborough

Faasse M, Ligthart M (2007) The American oyster drill, Urosalpinx cinerea (Say, 1822), introduced to the Netherlands - increased risks after ban on TBT? Aquat Invasion 2:402-406

Faasse M, Ligthart M (2008) De exotische tapijtschelp Ruditapes philippinarum (Adams \& Reeve, 1850) vestigt zich in Nederland. Het Zeepaard 68:175-179

Faasse M, Ligthart M (2009) American (Urosalpinx cinerea) and Japanese oyster drill (Ocinebrellus inornatus) (Gastropoda: Muricidae) flourish near shellfish culture plots in the Netherlands. Aquat Invasion 4:321-326

Gavio B, Fredericq S (2002) Grateloupia turuturu (Halymeniaceae, Rhodophyta) is the correct name of the non-native species in the Atlantic known as Grateloupia doryphora. Eur J Phycol 37:349-359

Gollasch S (1999) The Asian decapod Hemigrapsus penicillatus (de Haan, 1935) (Grapsidae, Decapoda) introduced in European waters: status quo and future perspective. Helgol Mar Res 52:359-366

Gollasch S (2006) Overview on introduced aquatic species in European navigational and adjacent waters. Helgol Mar Res 60:84-89

Gollasch S, Riemann-Zürneck K (1996) Transoceanic dispersal of benthic macrofauna: Haliplanella luciae (Verrill, 1898) (Anthozoa, Actinaria) found on a ship's hull in a shipyard dock in Hamburg harbour, Germany. Helgol Mar Res 50:253-258

Gollasch S, Haydar D, Minchin D, Reise K, Wolff WJ (2008) Introduced aquatic species of the North Sea coasts. In: Rilov G, Crooks JA (eds) Biological invasions in marine ecosystems: ecological, management, and geographic perspectives. Springer, Berlin, p 507-528

Goulletquer P, Bachelet G, Sauriau PG, Noël P (2002) Open Atlantic coast of Europe-a century of introduced species into French waters. In: Leppäkoski E, Gollasch S, Olenin S (eds) Invasive aquatic species of Europe. Distribution, impacts and management. Kluwer, Dordrecht, p 276-290

Grizel H, Héral M (1991) Introduction into France of the Japanese oyster (Crassostrea gigas). J Cons Int Explor Mer 47:399-403

Guiry MD, Guiry GM (2009) AlgaeBase. World-wide electronic publication, National University of Ireland, Galway. www.algaebase.org; accessed 12 February 2010

Hewitt CL, Campbell ML, Thresher RE, Martin RB and others (2004) Introduced and cryptogenic species in Port Phillip Bay, Victoria, Australia. Mar Biol 144:183-202 
Kerckhof F, Vink RJ, Nieweg DC, Post JNJ (2006) The veined whelk Rapana venosa has reached the North Sea. Aquat Invasion 1:35-37

Korringa P (1951) The shell of Ostrea edulis as a habitat. Arch Neerl Zool 10:32-152

Lützen J (1999) Styela clava Herdman (Urochordata, Ascidiacea), a successful immigrant to North West Europe: ecology, propagation and chronology of spread. Helgol Mar Res 52:383-391

Maggs CA, Stegenga H (1999) Red algal exotics on North Sea coasts. Helgol Mar Res 52:243-258

Mann R, Harding JM (2000) Invasion of the North American Atlantic coast by a large predatory Asian mollusc. Biol Invasion 2:7-22

Martel C, Viard F, Bourguet D, Garcia-Meunier P (2004) Invasion by the marine gastropod Ocinebrellus inornatus in France. II. Expansion along the Atlantic coast. Mar Ecol Prog Ser 273:163-172

McCarthy HP, Crowder LB (2000) An overlooked scale of global transport: phytoplankton species richness in ships' ballast water. Biol Invasion 2:321-322

McIvor L, Maggs CA, Provan J, Stanhope MJ (2001) rbcL sequences reveal multiple cryptic introductions of the Japanese red alga Polysiphonia harveyi. Mol Ecol 10:911-919

Mineur F, Belsher T, Johnson MP, Maggs CA, Verlaque M (2007) Experimental assessment of oyster transfers as a vector for macroalgal introductions. Biol Conserv 137:237-247

Nienhuis PH, Smaal AC (1994) The Oosterschelde estuary, a case-study of a changing ecosystem: an introduction. Hydrobiologia 282-283:1-14

Occhipinti Ambrogi A, Savini D (2003) Biological invasions as a component of global change in stressed marine ecosystems. Mar Pollut Bull 46:542-551

Reise K, Dankers N, Essink K (2005) Introduced species. In: Essink K, Dettmann C, Farke H, Laursen K, Lüerßen G, Marencic $H$, Wiersinga W (eds) Wadden Sea quality status report 2004. Common Wadden Sea Secretariat, Wilhelmshaven, Wadden Sea Ecosystem 19:155-161

Royer J, Ropert M, Mathieu M, Costil K (2006) Presence of spionid worms and other epibionts in Pacific oysters (Crassostrea gigas) cultured in Normandy, France. Aquaculture 253:461-474

Ruesink JL, Lenihan HS, Trimble AC, Heiman KW, Micheli F, Byers JE, Kay MC (2005) Introduction of non-native oysters: ecosystem effects and restoration implications. Annu Rev Ecol Evol Syst 36:643-689

Ruiz G, Fofonoff P, Carlton JT, Wonham MJ, Hines AH (2000) Invasion of coastal marine communities in North America: Apparent patterns, processes, and biases. Annu Rev Ecol Evol Syst 31:481-531

Editorial responsibility: Matthias Seaman, Oldendorf/Luhe, Germany
Schodduyn R (1931) Observations sur la flore et la faune des coquilles des huîtres. Bull Inst Oceanogr Monaco 568:1-20

Shatkin G, Shumway SE, Hawes R (1997) Considerations regarding the possible introduction of the Pacific oyster (Crassostrea gigas) to the Gulf of Maine: a review of global experience. J Shellfish Res 16:463-477

Smaal AC, Kater BJ, Wijsman J (2009) Introduction, establishment and expansion of the Pacific oyster Crassostrea gigas in the Oosterschelde (SW Netherlands). Helgol Mar Res 63:75-83

Smallegange M (1696) Nieuwe Cronyk van Zeeland. Johannes Meertens, Abraham van Soomeren, Middelburg

Spalding MD, Fox HE, Allen GR, Davidson N and others (2007) Marine ecoregions of the world: a bioregionalization of coastal and shelf areas. Bioscience 57:573-583

Stegenga H (2004) Lomentaria hakodatensis, een nieuwe 'invasiesoort' in Zeeland. Het Zeepaard 64:145-148

Stegenga H, Mol I, Prud'Homme van Reine WF, Lokhorst GM (1997) Checklist of the marine algae of the Netherlands. Gorteria Suppl 4:1-57

Stegenga H, Karremans M, Simons J (2007) Seaweeds of the former oyster pond near Yerseke, SW Netherlands. Gorteria 32:125-143

Stevenson RJ (1984) Procedures for mounting algae in a syrup medium. Trans Am Microsc Soc 103:320-321

Troost K (2010) Causes and effects of a highly successful marine invasion: case-study of the introduced Pacific oyster Crassostrea gigas in continental NW European estuaries. J Sea Res 64:145-165

Tydeman P (2008) Japanse oesters naar de (Wadden) zee gedragen? Het Zeepaard 68:109-114

> Verlaque M (2001) Checklist of the macroalgae of Thau Lagoon (Hérault, France), a hot spot for marine species introduction in Europe. Oceanol Acta 24:29-49

Wijsman JWM, De Mesel I (2009) Duurzame schelpdiertransporten. Rep C067/09, Wageningen IMARES, Yerseke

Wolff WJ (2005a) Development of human impact on suspension-feeding bivalves in coastal soft-bottom ecosystems. In: Dame RF, Olenin S (eds) The comparative roles of suspension-feeders in ecosystems. Springer, Dordrecht, p 317-330

Wolff WJ (2005b) Non-indigenous marine and estuarine species in the Netherlands. Zool Meded 79:1-116

Wolff WJ, Reise K (2002) Oyster imports as a vector for the introduction of alien species into Northern and Western European coastal waters. In: Leppäkoski E, Gollasch S, Olenin S (eds) Invasive aquatic species of Europe. Distribution, impact and management. Kluwer, Dordrecht, p 193-205

Submitted: February 7, 2011; Accepted: April 12, 2011

Proofs received from author(s): May 26, 2011 